\title{
GLOSA DO WYROKU WSA W BIAŁYMSTOKU Z DNIA 27 LUTEGO 2014 R., II SA/BK 702/13
}

\section{COMMENTARY TO THE JUDGEMENT OF THE VOIVODESHIP ADMINISTRATIVE COURT IN BIAŁYSTOK OF 27 FEBRUARY 2014, II SA/BK $702 / 13$}

W glosowanym orzeczeniu WSA w Białymstoku stwierdził, iż przepis art. 5 ust. 7 ustawy o utrzymaniu czystości ${ }^{1}$ nie daje podstawy do nałożenia w drodze decyzji administracyjnej obowiązku zawarcia umowy - zarówno na wywóz nieczystości z szamba ani tym bardziej z osadnika oczyszczalni ścieków. Brak umowy stanowi podstawę do wszczęcia postępowania w trybie

* Doktor nauk prawnych, adiunkt w Katedrze Prawa Ochrony Środowiska, Wydział Prawa i Administracji, Uniwersytet Mikołaja Kopernika w Toruniu.

1 Ustawa z dnia 13 września 1996 r. utrzymaniu czystości i porządku w gminach, tekst jedn. Dz.U. z 2013 r., poz. 1399 ze zm., zwana dalej ustawą o utrzymaniu czystości lub określana skrótem u.u.c. 
art. 6 ust. 7 i ust. 1 ustawy i to wówczas, gdy stan faktyczny wypełnia przesłanki cyt. przepisu.

Przedmiotowe orzeczenie wydane zostało na skutek skargi na decyzję Samorządowego Kolegium Odwoławczego uchylającą decyzję Burmistrza o nałożeniu na właściciela obowiązku podpisania umowy na wywóz nieczystości z osadnika gnilnego przydomowej oczyszczalni ścieków i przekazującą sprawę do ponownego rozpoznania.

Decyzja administracyjna w przedmiotowej sprawie wydana została na wniosek właścicieli sąsiedniej nieruchomości, którzy zażądali wszczęcia postępowania administracyjnego w sprawie o odprowadzanie nieczystości ciekłych z budynku mieszkalnego położonego na sąsiedniej nieruchomości. W toku postępowania organ I instancji ustalił, iż na przedmiotowej nieruchomości znajduje się przydomowa oczyszczalnia ścieków. Organ stwierdził, iż właściciel powinien zawrzeć umowę na wywóz osadów z osadnika gnilnego, w związku z czym wydał, na podstawie art. 5 ust. 7 u.u.c., decyzję o nałożeniu obowiązku zawarcia umowy w zakresie nieczystości z osadnika gnilnego. Na skutek wniesionego odwołania decyzja ta została uchylona przez Samorządowe Kolegium Odwoławcze, jako wydana bez podstawy prawnej. Organ II instancji wskazał, iż w myśl art. 5 ust. 1 pkt 2 u.u.c. przyłączenie nieruchomości do sieci kanalizacyjnej nie jest obowiązkowe, jeżeli nieruchomość jest wyposażona w przydomową oczyszczalnię ścieków spełniającą wymagania określone w przepisach odrębnych. Z kolei, zgodnie $\mathrm{z}$ art. 5 ust. 7 ustawy, w przypadku stwierdzenia niewykonania obowiązków, o których mowa w ust. 1-4, wójt (burmistrz, prezydent miasta) wydaje decyzję nakazującą wykonanie obowiązku. Przepis ten nie daje podstawy do nałożenia obowiązku zawarcia umowy - zarówno na wywóz nieczystości z szamba ani tym bardziej z osadnika oczyszczalni ścieków. Brak umowy stanowi podstawę do wszczęcia postępowania w trybie art. 6 ust. 7 i ust. 1 u.u.c. i to wówczas, gdy stan faktyczny wypełnia przesłanki cyt. przepisu. Organ wskazał również na zasadność argumentów odwołującego się, co do braku podstaw udziału w postępowaniu „wnioskodawców” - właścicieli sąsiedniej nie3/2014 ruchomości. Postępowanie administracyjne, prowadzone na 
podstawie art. 5 ust. 7 lub 6 ust. 7 u.u.c. jest postępowaniem prowadzonym z urzędu, którego stroną jest tylko właściciel lub współwłaściciele nieruchomości. Organ jednocześnie wskazał, że sąsiad nieruchomości ma prawo ochrony swoich interesów $\mathrm{w}$ postępowaniu administracyjnym $\mathrm{w}$ stanie opisanym $\mathrm{w}$ sprawie poprzez postępowanie $\mathrm{z}$ art. 29 Prawa wodnego ${ }^{2}$, lub w trybie ochrony cywilnej poprzez roszczenie z art. 144 Kodeksu cywilnego ${ }^{3}$. W ocenie Samorządowego Kolegium Odwoławczego $\mathrm{z}$ analizy podania o wszczęcie postępowania wynikało oczekiwanie wnioskodawcy dotyczące nielegalnego i niezgodnego z prawem odprowadzania ścieków z sąsiedniej nieruchomości, co sugeruje postępowanie w trybie art. 29 Prawa wodnego. Zdaniem organu odwoławczego konieczne było ponowne przeanalizowanie wniosku strony i w przypadku, gdy nie toczy się postępowanie $\mathrm{w}$ trybie 29 Prawa wodnego, to takie postępowanie należało wszcząć, a jeżeli postępowanie się toczy, to wniosek należało włączyć do tego toczącego się postępowania.

Z decyzją SKO nie zgodziła się „wnioskodawczyni” (właścicielka sąsiedniej nieruchomości).

Wojewódzki Sąd Administracyjny w Białymstoku uchylił decyzję Samorządowego Kolegium Odwoławczego. Sąd ten zgodził się z argumentacją organu administracyjnego II instancji, co do nieadekwatności wskazanej w decyzji podstawy prawnej, tj. art. 5 ust. 7 u.u.c. z treścią podjętego rozstrzygnięcia oraz co do wyznaczenia kręgu podmiotów, którym przysługuje statut strony w przedmiotowym postępowaniu. Sąd nie podzielił natomiast stanowiska tegoż organu co do potrzeby przekazania sprawy do ponownego rozpoznania przez organ I instancji. W ocenie Wojewódzkiego Sądu Administracyjnego przepis art. 5 ust. 7 u.u.c. nie może stanowić podstawy prawnej nałożenia na właściciela nieruchomości obowiązku zawarcia umowy na opróżnienie osadnika gnilnego przydomowej oczyszczalni ścieków. Zgodnie z art. 5 ust. 7 i 8 u.u.c. w przypadku stwierdzenia niewykona-

2 Ustawa z dnia 18 lipca 2001 r. Prawo wodne, tekst jedn. Dz.U. z 2012 r., poz. 145 ze zm., zwana dalej Prawem wodnym lub określana skrótem p.w.

3 Ustawa z dnia 23 kwietnia 1964 r. Kodeks cywilny, tekst jedn. Dz.U z 2014 r., poz. 121. 
nia obowiązków, o których mowa w art. 5 ust. 1 pkt 1, 2, 4, 5 , ust. $2-4$ u.u.c., wójt (burmistrz, prezydent miasta) wydaje decyzję nakazującą wykonanie obowiązku. Podstawę wydania przez wójta (burmistrza, prezydenta miasta) decyzji w oparciu o wskazany przepis stanowi stwierdzenie istnienia normatywnego obowiązku wynikającego ze wskazanych przepisów, a następnie ustalenie, iż obowiązek ten nie jest przez właściciela nieruchomości wykonywany. W ocenie sądu żaden z przepisów art. 5 ust. $1-4$ u.u.c. nie nakłada na właściciela nieruchomości obowiązku zawarcia umowy na opróżnianie osadnika gnilnego przydomowej oczyszczalni ścieków. Wojewódzki Sąd Administracyjny wskazał, iż ewentualna podstawę rozstrzygnięcia organu administracyjnego mógłby stanowić przepis art. 6 ust. 7 u.u.c., zgodnie z którym wójt (burmistrz, prezydent miasta) wydaje z urzędu decyzję, w której ustala obowiązek uiszczania opłat za odbieranie odpadów komunalnych lub opróżnianie zbiorników bezodpływowych, wysokość opłat, terminy uiszczania opłat oraz sposób i terminy udostępniania pojemników lub zbiorników w celu ich opróżnienia, w przypadku gdy właściciel nieruchomości nie zawarł umowy, o której mowa w art. 6 ust. 1 u.u.c. na opróżnianie zbiorników bezodpływowych lub odbieranie odpadów komunalnych. Sąd jednocześnie zastrzegł, iż brak umowy stanowi podstawę, do wszczęcia postępowania w trybie art. 6 ust. 7 i ust. 1 ustawy i to wówczas, gdy stan faktyczny wypełnia przesłanki tych przepisów, nie wyjaśniając ostatecznie, czy istnieją $\mathrm{w}$ polskim systemie prawnym podstawy do zobowiązania właściciela nieruchomości, w trybie decyzji administracyjnej, do zawarcia umowy na opróżnianie osadnika gnilnego przydomowej oczyszczalni ścieków.

Pomimo znikomej warstwy analitycznej glosowane orzeczenie zasługuje na skomentowanie ze względu na poruszony w nim problem obowiązków właścicieli nieruchomości na których zlokalizowane są przydomowe oczyszczalnie ścieków oraz związanych z tym uprawnień organów administracji publicznej, w kontekście ustawy o utrzymaniu czystości i porządku w gminie.

Ustawa o utrzymaniu czystości, w zakresie, w jakim wy3/2014 znacza sferę obowiązków właścicieli nieruchomości, należy do 
aktów prawnych ograniczających prawa i wolności jednostki ${ }^{4}$. Wynika stąd obowiązek dokonywania ścisłej wykładni przepisów zawierających normy prawne określające te obowiązki. Jak wynika z art. 1 pkt 1 u.u.c. ustawa określa m.in. obowiązki właścicieli nieruchomości ${ }^{5}$, dotyczące utrzymania czystości i porządku. Zakres tych obowiązków został sformułowany w art. 5 ust. 1 u.u.c. Przepis ten nakłada na właściciela nieruchomości obowiązek: 1) wyposażenia nieruchomości w pojemniki służące do zbierania odpadów komunalnych oraz utrzymywania tych pojemników w odpowiednim stanie sanitarnym, porządkowym i technicznym, 2) przyłączenia nieruchomości do istniejącej sieci kanalizacyjnej lub, w przypadku gdy budowa sieci kanalizacyjnej jest technicznie lub ekonomicznie nieuzasadniona, wyposażenia nieruchomości w zbiornik bezodpływowy nieczystości ciekłych lub w przydomową oczyszczalnię ścieków bytowych, spełniające wymagania określone w przepisach odrębnych; przyłączenie nieruchomości do sieci kanalizacyjnej nie jest obowiązkowe, jeżeli nieruchomość jest wyposażona w przydomową oczyszczalnię ścieków spełniającą wymagania określone w przepisach odrębnych, 3) zbierania powstałych na terenie nieruchomości odpadów komunalnych zgodnie z wymaganiami określonymi $\mathrm{w}$ regulaminie, 4) gromadzenie nieczystości ciekłych w zbiornikach bezodpływowych, 5) pozbywania się zebranych na terenie nieruchomości odpadów komunalnych oraz nieczystości ciekłych w sposób zgodny z przepisami ustawy i przepisami odrębnymi, 6) uprzątnięcia błota, śniegu, lodu i innych zanieczyszczeń z chodników położonych wzdłuż nierucho-

4 W doktrynie prawa ochrony środowiska wyrażany jest pogląd, iż ochrona środowiska i obowiązki w tym zakresie należą do istoty własności. Z samej istoty własności wynika bowiem obowiązek uwzględnienia aspektów społecznych, co z kolei prowadzi do wniosku, iż chodzi o takie zachowania właściciela, które nie będą naruszać środowiska. B. Rakoczy, Ograniczenia praw i wolności jednostki ze względu na ochronę środowiska w Konstytucji Rzeczypospolitej Polskiej, Toruń 2006, s. 315,

5 Zgodnie z art. 2 ust. 1 pkt 4 u.u.c. ilekroć w ustawie jest mowa o właścicielu nieruchomości należy przez to rozumieć także współwłaścicieli, użytkowników wieczystych oraz jednostki organizacyjne i osoby posiadające nieruchomości w zarządzie lub użytkowaniu, a także inne podmioty władające nieruchomością. 
mości; właściciel nieruchomości nie jest obowiązany do uprzątnięcia chodnika, na którym jest dopuszczony płatny postój lub parkowanie pojazdów samochodowych, 7) realizacji innych obowiązków określonych w regulaminie. Odnosząc powyższą regulację do przedmiotu sprawy - obowiązku usuwania osadów ściekowych z przydomowej oczyszczalni ścieków - należy poddać szczegółowej analizie obowiązek wskazany w pkt 2 i 5.

Jednym z obowiązków właściciela nieruchomości w zakresie utrzymania porządku i czystości jest obowiązek przyłączenia nieruchomości do sieci kanalizacyjnej. Obowiązek ten zostaje wyłączony w dwóch przypadkach: 1) gdy budowa sieci kanalizacyjnej jest technicznie lub ekonomicznie nieuzasadniona, 2) gdy nieruchomość jest wyposażona w przydomową oczyszczalnię ścieków. W pierwszym przypadku, obowiązek przyłączenia nieruchomości do sieci kanalizacyjnej zostaje zastąpiony obowiązkiem wyposażenia nieruchomości w zbiornik bezodpływowy nieczystości ciekłych lub w przydomową oczyszczalnię ścieków bytowych. W drugim przypadku, nie powstaje obowiązek przyłączenia nieruchomości do sieci kanalizacyjnej, jak również nie powstaje żaden obowiązek alternatywny. Reasumując, należy przyjąć, iż w przypadku wyposażenia nieruchomości w przydomową oczyszczalnię ścieków bytowych, przepis art. 5 ust. 1 pkt 2 u.u.c. nie stanowi dla właściciela nieruchomości źródła jakiegokolwiek obowiązku.

Zgodnie z art. 5 ust. 1 pkt 3b u.u.c. właściciel nieruchomości ma obowiązek pozbywania się zebranych na terenie nieruchomości odpadów komunalnych oraz nieczystości ciekłych w sposób zgodny z przepisami ustawy i przepisami odrębnymi. W świetle analizowanej sprawy powstaje zasadnicze pytanie, czy osady ściekowe z przydomowych oczyszczalni ścieków są nieczystościami ciekłymi lub odpadem komunalnym. Pojęcie komunalnych osadów ściekowych zdefiniowane zostało, w art. 3 ust. 1 pkt 4 ustawy o odpadach ${ }^{6}$, jako pochodzący z oczyszczalni ścieków osad z komór fermentacyjnych oraz innych instalacji służących do oczyszczania ścieków komunalnych oraz

6 Ustawa z dnia 14 grudnia 2012 r. o odpadach, Dz.U. z 2013 r., poz. 21 ze zm., zwana dalej ustawa o odpadach lub określana skrótem u.o. 
innych ścieków o składzie zbliżonym do składu ścieków komunalnych. Należy wyraźnie podkreślić, iż na gruncie ustawy o odpadach, brak jest jakichkolwiek podstaw do różnicowania komunalnych osadów ściekowych ze względu na rozróżnienie komunalnych oczyszczalni ścieków i oczyszczalni przydomowych. Nie ulega wątpliwości, iż substancje gromadzące się w osadnikach gnilnych przydomowych oczyszczalni ścieków spełniają warunki definicyjne komunalnych osadów ściekowych. Dla potrzeb ustawy o utrzymaniu czystości ustawodawca zdefiniował nieczystości płynne jako ścieki gromadzone przejściowo w zbiornikach bezodpływowych. Pojęcie ścieków zostało przez polskiego ustawodawcę zdefiniowane, za pomocą definicji legalnej, w trzech odrębnych aktach prawnych: ustawie prawo ochrony środowiska7, ustawie prawo wodne oraz ustawie o zbiorowym zaopatrzeniu w wodę i odprowadzeniu ścieków ${ }^{8}$. We wszystkich tych aktach prawnych zawarta została identyczna definicja zgodnie z którą ściekami są wprowadzane do wód lub do ziemi wody wymienione w 6 odrębnych kategoriach ${ }^{9}$

7 Ustawa z dnia 27 kwietnia 2001 r. Prawo ochrony środowiska, tekst jedn. Dz.U. z 2013 r., poz. 1232 ze zm.

8 Ustawa z dnia 7 czerwca 2001 r. o zbiorowym zaopatrzeniu w wodę i zbiorowym odprowadzaniu ścieków, tekst jedn. Dz. U. z 2006 r., Nr 123, poz. 858 ze zm.

9 Są to następujące kategorie: a) wody zużyte, w szczególności na cele bytowe lub gospodarcze, b) wody opadowe lub roztopowe, ujęte w otwarte lub zamknięte systemy kanalizacyjne, pochodzące z powierzchni zanieczyszczonych o trwałej nawierzchni, w szczególności z miast, portów, lotnisk, terenów przemysłowych, handlowych, usługowych i składowych, baz transportowych oraz dróg i parkingów, c) wody odciekowe ze składowisk odpadów oraz obiektów unieszkodliwiania odpadów wydobywczych, w których są składowane odpady wydobywcze niebezpieczne oraz odpady wydobywcze inne niż niebezpieczne i obojętne, miejsc magazynowania odpadów, wykorzystane solanki, wody lecznicze i termalne, d) wody pochodzące z odwodnienia zakładów górniczych, z wyjątkiem wód wtłaczanych do górotworu, jeżeli rodzaje i ilość substancji zawartych w wodzie wtłaczanej do górotworu są tożsame z rodzajami i ilościami substancji zawartych w pobranej wodzie, e) wody wykorzystane, odprowadzane z obiektów chowu lub hodowli ryb łososiowatych, f) wody wykorzystane, odprowadzane z obiektów chowu lub hodowli ryb innych niż łososiowate albo innych organizmów wodnych, o ile produkcja tych ryb lub organizmów, rozumiana jako średnioroczny przyrost masy tych ryb albo tych organizmów w poszczególnych latach cyklu produkcyjnego, prze- 
oraz ciekłe odchody zwierzęce, z wyjątkiem gnojówki i gnojowicy przeznaczonych do rolniczego wykorzystania w sposób i na zasadach określonych w ustawie z dnia 10 lipca 2007 r. o nawozach i nawożeniu ${ }^{10}$. Jak słusznie zauważa W. Radecki, jeżeli istotą ścieków w rozumieniu prawnym jest to, że są one wprowadzane do wód lub do ziemi, to zrozumiałe jest, że nieczystości ciekłe zgromadzone w zbiornikach bezodpływowych nie są ściśle rzecz biorąc ściekami, a intencja ustawodawcy jest taka, że nieczystości ciekłe są jedynie przejściowo gromadzone w zbiornikach bezodpływowych, staną się zaś ściekami wtedy, kiedy zostaną wprowadzone do wód lub do ziemi ${ }^{11}$. Porównanie definicji komunalnych osadów ściekowych oraz definicji ścieków prowadzi do wniosku, iż osady te nie są ściekami, i z tego już powodu nie mogą stanowić nieczystości płynnych w rozumieniu ustawy o utrzymaniu czystości. Ponadto w przypadku osadów ściekowych nie zostaje spełniony również drugi warunek definicji nieczystości płynnych z art. 2 ust. 1 pkt 1 u.u.c., to jest gromadzenia przejściowo w zbiornikach bezodpływowych. Technologia przydomowych oczyszczalni ścieków, co do zasady, zakłada przepływowość osadników.

Przyjmując, iż osady z przydomowych oczyszczalni ścieków nie stanowią nieczystości ciekłych w rozumieniu ustawy o utrzymaniu czystości należy rozważyć ewentualną ich kwalifikację do grupy odpadów komunalnych, którymi zgodnie z art. 3 ust. 1 pkt 7 u.o., są odpady powstające w gospodarstwach domowych, z wyłączeniem pojazdów wycofanych z eksploatacji, a także odpady niezawierające odpadów niebezpiecznych pochodzące od innych wytwórców odpadów, które ze względu na swój charakter lub skład są podobne do odpadów powstających w gospodarstwach domowych. W doktrynie prawa ochrony środowiska wyrażony został jednoznacznie pogląd, iż komunalne

kracza $1500 \mathrm{~kg} \mathrm{z} 1$ ha powierzchni użytkowej stawów rybnych tego obiektu w jednym roku danego cyklu.

10 Dz. U. Nr 147, poz. 1033 ze zm.

11 W. Radecki, Utrzymanie czystości i porządku w gminach. Komentarz, Warszawa 2012, wersja elektroniczna. 
osady ściekowe nie są odpadem komunalnym ${ }^{12}$. Argumentem przemawiającym za tym stanowiskiem jest przede wszystkim sklasyfikowanie ustabilizowanych komunalnych osadów ściekowych w grupie 19 katalogu odpadów w rozumieniu §2 rozporządzenia w sprawie katalogu odpadów ${ }^{13}$. Grupa ta obejmuje odpady z instalacji i urządzeń służących zagospodarowaniu odpadów, z oczyszczalni ścieków oraz z uzdatniania wody pitnej i wody do celów przemysłowych. Odrębną, 20 grupę, stanowią odpady komunalne.

Przyjmując, iż osady ściekowe nie są ani nieczystościami ciekłymi, ani też odpadami komunalnymi należy stwierdzić, iż usuwanie osadów ściekowych z przydomowych oczyszczalni ścieków nie jest objęte zakresem normy prawnej zawartej w art. 5 ust. 1 pkt 3b u.u.c., zgodnie z którą właściciel nieruchomości ma obowiązek pozbywania się zebranych na terenie nieruchomości odpadów komunalnych oraz nieczystości ciekłych w sposób zgodny z przepisami ustawy i przepisami odrębnymi. Również żaden z pozostałych obowiązków właściciela nieruchomości, określony w art. 5 ust. 1 u.u.c. nie odnosi się do usuwania z nieruchomości osadów ściekowych powstałych w wyniku funkcjonowania przydomowej oczyszczalni ścieków.

Poczynione ustalenia, dotyczące braku możliwości zakwalifikowania osadów ściekowych do kategorii odpadów komunalnych lub nieczystości ciekłych wykluczają również możliwość objęcia czynności usuwania osadów ściekowych dyspozycją art. 6 ust.1 u.u.c. Zgodnie z tym przepisem właściciele nieruchomości, którzy pozbywają się z terenu nieruchomości nieczystości ciekłych, oraz właściciele nieruchomości, którzy nie są obowiązani do ponoszenia opłat za gospodarowanie odpadami komunalnymi na rzecz gminy, wykonując obowiązek określony w art. 5 ust. 1 pkt 3b, są obowiązani do udokumentowania w formie umowy korzystania z usług wykonywanych przez: 1) gminną jednostkę organizacyjną lub przedsiębiorcę posiadającego zezwolenie

12 W. Radecki, op.cit.; J. Jerzmański, [w:] Ustawa o odpadach. Komentarz, red. J. Jerzmański, Wrocław 2008, s. 79.

13 Rozporządzenie Ministra Środowiska z dnia 27 września 2001 r. w sprawie katalogu odpadów, Dz. U. z 2001 r., Nr 112, poz. 1206. 
na prowadzenie działalności w zakresie opróżniania zbiorników bezodpływowych i transportu nieczystości ciekłych lub 2) gminną jednostkę organizacyjną lub przedsiębiorcę odbierającego odpady komunalne od właścicieli nieruchomości, wpisanego do rejestru działalności regulowanej, o którym mowa w art. 9b ust. 2 u.u.c. - przez okazanie takich umów i dowodów uiszczania opłat za te usługi. Już w samej treści art. 6 ust. 1 u.u.c. ustawodawca expressis verbis nawiązał do obowiązku wyrażonego w art. 5 ust. 1 pkt 3b u.u.c. W związku z ustaleniem, iż obowiązek ten nie obejmuje usuwania osadów ściekowych z przydomowych oczyszczalni ścieków należy przyjąć, że również obowiązki określone w art. 6 ust. 1 u.u.c. nie dotyczą usuwania osadów ściekowych. Ustalenie, iż na gruncie ustawy o utrzymaniu czystości brak jest podstaw prawnych dla przyjęcia istnienia po stronie właściciela nieruchomości obowiązku legitymowania się umową na wywóz osadów ściekowych z przydomowej oczyszczalni ścieków przesądza o braku możliwości orzekania o tym obowiązku w drodze decyzji administracyjnej, wydawanej na podstawie art. 6 ust. 7 u.u.c. Na marginesie należy jednocześnie zaznaczyć, iż w obecnym stanie prawnym w ogóle nie istnieje możliwość wydania przez organ administracyjny decyzji zobowiązującej do zawarcia umowy np. o wywóz nieczystości płynnych. Zakres decyzji administracyjnej, wydawanej w związku ze stwierdzeniem niedopełnienia obowiązku określonego w art. 6 ust. 1 u.u.c., zdeterminowany został treścią art. 6 ust. 7 u.u.c., zgodnie z którym wójt (burmistrz, prezydent miasta) wydaje z urzędu decyzję, w której ustala: 1) obowiązek uiszczania opłat za odbieranie odpadów komunalnych lub opróżnianie zbiorników bezodpływowych, 2) wysokość opłat 3) terminy uiszczania opłat, oraz 4) sposób i terminy udostępniania pojemników lub zbiorników w celu ich opróżnienia. Rozwiązanie to wynika z faktu, iż zgodnie z art. 6 ust. 6 u.u.c. na gminie ciąży obowiązek zorganizowania odbierania odpadów komunalnych oraz opróżnianie zbiorników bezodpływowych w przypadku właścicieli nieruchomości, którzy nie zawarli umów, o których mowa w art. 6 ust. 1 u.u.c.

W świetle poczynionych ustaleń należy jednoznacznie stwierdzić, iż ani przepis art. 5 ust. 7 u.u.c., ani art. 6 ust. 7 3/2014 u.u.c. nie stanowi podstawy orzekania w trybie decyzji admini- 
stracyjnej o obowiązkach właściciela nieruchomości w zakresie usuwania osadów ściekowych z przydomowej oczyszczalni ścieków. Poczynienie przez sąd uwagi odsyłającej do ewentualnego zastosowania przepisu art. 6 ust. 7 u.u.c., nawet z zastrzeżeniem, „gdy stan faktyczny wypełnia przesłanki cyt. przepisu”, należy ocenić krytycznie gdyż może stanowić ona źródło nieuzasadnionego przekonania, iż w określonych okolicznościach faktycznych (np. braku umowy na wywóz osadu) hipotezą normy zawartej w art. 6 ust. 7 w związku z art. 6 ust. 1 u.u.c. objęci zostaną również właściciele nieruchomości na których zlokalizowane są przydomowe oczyszczalnie ścieków.

Analiza przepisów ustawy o utrzymaniu czystości prowadzi do ogólniejszego wniosku, iż ustawa ta nie obejmuje zakresem swej regulacji obowiązków właścicieli nieruchomości w zakresie funkcjonowania przydomowych oczyszczalni ścieków. Należy jednocześnie zwrócić uwagę na treść art. 3 ust. 3 pkt 2 u.u.c., zgodnie z którym gminy prowadzą ewidencję przydomowych oczyszczalni ścieków w celu kontroli częstotliwości i sposobu pozbywania się komunalnych osadów ściekowych oraz w celu opracowania planu rozwoju sieci kanalizacyjnej. W świetle poczynionych ustaleń realizacja przez gminę wskazanego obowiązku, na gruncie ustawy o utrzymaniu czystości, jest faktycznie niemożliwa wobec braku podstaw normatywnych obowiązków właścicieli nieruchomości w tym zakresie.

Brak uregulowania sytuacji prawnej właścicieli nieruchomości wyposażonych w przydomowe oczyszczalnie ścieków, na poziomie ustawy o utrzymaniu czystości, co do obowiązków związanych z funkcjonowaniem tych oczyszczalni powoduje, iż wyłączną regulacją prawną w tym zakresie jest ustawa o odpadach oraz wydane na jej podstawie przepisy wykonawcze ${ }^{14}$. Oznacza to zrównanie sytuacji prawnej właścicieli nieruchomości, a tym samym właścicieli przydomowych oczyszczalni ścieków, jako wytwórców odpadów z sytuacją przedsiębiorstw prowadzących działalność gospodarczą w zakresie oczyszczania ścieków. Konsekwencją tego jest nałożenie na właścicieli przy-

14 W szczególności rozporządzenie Ministra Środowiska z 13 lipca 2010 r. w sprawie komunalnych osadów ściekowych, Dz. U. Nr 137, poz. 924. 
domowych oczyszczalni ścieków, w zakresie gospodarowania komunalnym osadem ściekowym, obowiązków wynikających z ustawy o odpadach. Rozwiązanie to może wywoływać wątpliwości co do zachowania, wynikającej z art. 31 ust. 3 Konstytucji $\mathrm{RP}$, zasady proporcjonalności. Uważam, iż w pełni uzasadnionym byłoby uregulowanie obowiązków właścicieli przydomowych oczyszczalni ścieków, w zakresie usuwania osadu ściekowego bezpośrednio w ustawie o utrzymaniu czystości, w sposób niepozostawiający wątpliwości zarówno co do treści, ciążących na właścicielach obowiązków, jak i kompetencji organów administracji publicznej w tym zakresie ${ }^{15}$.

\section{BIBLIOGRAFIA}

Pawlak M., Pilarski K., Perspektywy rozwoju gospodarki osadowej dla przydomowych oczyszczalni ścieków, [w:] Foresight w przedsiębiorstwie, K. Borodako, M. Nowosielski (red.), Instytut Zachodni Poznań 2012.

Radecki W., Utrzymanie czystości i porządku w gminach. Komentarz, Warszawa 2012.

Rakoczy B., Ograniczenia praw i wolności jednostki ze względu na ochronę środowiska w Konstytucji Rzeczypospolitej Polskiej, Toruń 2006.

Ustawa o odpadach. Komentarz, red. J. Jerzmański, Wrocław 2008.

Kontakt e-mail:

szalew@law.umk.pl

15 Potrzeba wprowadzenia odrębnych wymogów prawnych i procedur postępowania dla osadów ściekowych z przydomowych oczyszczalni ścieków, ze względu na wysoki stopień możliwości ich przyrodniczego wykorzystania, postulowana jest również przez przedstawicieli nauk technicznych. Stworzenie odpowiednich uwarunkowań prawnych w tym zakresie może mieć istotny wpływ na rozwój proekologicznych rozwiązań technologicznych w zakresie przetwarzania i wykorzystywania osadów ściekowych pochodzących przydomowych oczyszczalni ścieków. Zob. M. Pawlak, K. Pilarski, Perspektywy rozwoju gospodarki osadowej dla przydomowych oczyszczalni ścieków, [w:] Foresight w przedsiębiorstwie, K. Borodako, M. Nowosielski (red.), Instytut Zachodni Poznań 2012, s. 92. 